\title{
Effect of Co-Existing Biologically Relevant Molecules and Ions on DNA Photocleavage Caused by Pyrene and its Derivatives
}

\author{
Shuguang Wang ${ }^{1}$ and Hongtao $\mathrm{Yu}^{{ }^{*}}$ \\ ${ }^{1}$ Department of Chemistry, Jackson State University, Jackson, MS 39217, USA \\ *Correspondence to Dr. Hongtao Yu. E-mail: yu@ccaix.jsums.edu
}

Received: 15 November 2004 / Accepted: 06 February 2005 / Published: 30 April 2005

\begin{abstract}
Inorganic ions, coenzymes, amino acids, and saccharides could co-exist with toxic environmental chemicals, such as polycyclic aromatic hydrocarbons (PAHs), in the cell. The presence of these co-existing chemicals can modulate the toxicity of the PAHs. One of the genotoxic effects by PAHs is light-induced cleavage, or photocleavage, of DNA. The effect of inorganic ions $\mathrm{I}^{-}, \mathrm{Na}^{+}, \mathrm{Ca}^{2+}, \mathrm{Mg}^{2+}, \mathrm{Fe}^{3+}, \mathrm{Mn}^{2+}, \mathrm{Cu}^{2+}$, and $\mathrm{Zn}^{2+}$ and biological molecules riboflavin, histidine, mannitol, nicotinamide adenine dinucleotide (NAD), glutathione, and glutamic acid on the DNA photocleavage by pyrene, 1-hydroxypyrene (1-HP), and 1-aminopyrene (1-AP), is studied. The non-transition metal ions $\mathrm{Na}^{+}, \mathrm{Ca}^{2+}$, and $\mathrm{Mg}^{2+}$, usually have very little inhibitory effects, while the transition metal ions $\mathrm{Fe}^{3+}, \mathrm{Cu}^{2+}$, and $\mathrm{Zn}^{2+}$ enhance, $\mathrm{Mn}^{2+}$ inhibits the DNA photocleavage. The effect by biological molecules is complex, depending on the photochemical reaction mechanisms of the compounds tested (1-AP, 1$\mathrm{HP}$ and pyrene) and on the chemical nature of the added biological molecules. Riboflavin, histidine, and mannitol enhance DNA photocleavage by all three compounds, except that mannitol has no effect on the photocleavage of DNA by pyrene. Glutathione inhibits the DNA photocleavage by 1-AP and 1-HP, but has no effect on that by pyrene. NAD enhances the DNA photocleavage by 1-AP, but has no effect on that by 1-HP and pyrene. Glutamic acid enhances the DNA photocleavage by 1-AP and pyrene, but inhibits that by 1-HP. These results show that the co-existing chemicals may have a profound effect on the toxicity of PAHs, or possibly on the toxicity of many other chemicals. Therefore, if one studies the toxic effects of PAHs or other toxic chemicals, the effect of the coexisting chemicals or ions needs to be considered.
\end{abstract}

Keywords: PAH, pyrene, 1-aminopyrene, 1-hydroxypyrene, photo-induced DNA cleavage; biologically relevant ions and molecules

\section{Introduction}

Polycyclic aromatic hydrocarbons (PAHs) are widespread environmental pollutants produced during forest fire, volcanic eruption, incomplete burning of fossil fuels, petroleum products, as well as during tobacco smoke, food processing, operation of machinery including automobiles, airplanes and ships [1,2]. Chemical carcinogenesis studies of PAHs started in 1915 when Yamagawa and Ichikawa observed that repeated application of coal tar on rabbits over extended periods induced skin carcinomas on the rabbit ears [3]. The carcinogenic potential for PAHs was recognized in 1930 when Kennaway and Hiegar synthesized dibenz $[a, h]$ anthrancene and determined its carcinogenicity [4]. However, the fluorescence spectrum of dibenz $[a, h]$ anthrancene did not correspond exactly to that of the carcinogenic components of coal tar. Further investigation of other carcinogenic components of coal tar by Cook et al led to the discovery of benzo[a]pyrene as one of the major carcinogenic components [5]. Since these pioneering studies, more than 30 PAHs and several hundred of their derivatives have been reported to exhibit some carcinogenic effects [6-8]. It is reported in the $8^{\text {th }}$ Report on Carcinogens that exposure to PAHs has been linked to the development of skin and lung cancers (National Toxicology Program, 1998).

Under physiological conditions, PAHs themselves are inert molecules and generally considered nontoxic toward biological systems. PAHs affect humans usually after being activated by metabolic enzymes or light $[9,10]$. Many PAHs can be metabolized into diol epoxides, diones and other reactive intermediates that are capable of reacting with cellular DNA to form PAHDNA covalent adducts or cause other forms of cellular damages [2,11-13]. Another pathway for PAH activation 
is photo-activation [10]. PAHs are activated by absorption of light energy and excited to their upper energy states. The excited state energy can be lost by emitting light or heat, or transferred to molecular oxygen, solvent molecules, or biological molecules in the cell to generate reactive intermediates that can damage cellular constituents such as cell membrane, nucleic acids, or proteins. It has been observed that PAHs can cause DNA single strand cleavage and DNAPAH adduct formation upon UVA light irradiation [10, 14-17]. Generally, PAHs are more toxic when exposed to simulated solar radiation than if it is kept in the dark and the increase in toxicity can exceed 100 -fold $[18,19]$. Thus, the light-activated PAHs can cause cellular damages and exert toxicity including carcinogenicity. Since co-existing chemicals are usually involved in the photochemical processes of the phototoxic compounds, it is understandable that the co-existing chemicals should have a profound effect on the photochemical reaction as well as the phototoxic effects of these compounds.

Through various pathways PAHs are known to be able to enter into the cells and co-exist with many other biological chemicals in the cell. It is logical to assume that the co-existing chemicals should have a profound effect on light-induced DNA cleavage by PAHs, and therefore, on the toxicity of these compounds if the cells, such as skin cells, are subject to light irradiation. Thus, we wish to report the effect of biologically relevant inorganic ions and molecules on the light-induced DNA cleavage by pyrene and its polar derivatives, 1aminopyrene (1-AP) and 1-hydroxypyrene (1-HP). Pyrene was chosen as a representative PAH and 1-AP and 1-HP as its polar derivatives. The biologically relevant ions, $\mathrm{Na}^{+}, \mathrm{K}^{+}, \mathrm{Mg}^{2+}, \mathrm{Ca}^{2+}, \mathrm{Fe}^{3+}, \mathrm{Cu}^{2+}, \mathrm{Mn}^{2+}$, $\mathrm{Zn}^{2+}$, and $\mathrm{I}^{-}$and molecules, riboflavin, nicotinamide adenine dinucleotide (NAD), histidine, mannitol, glutathione, and glutamic acid, are chosen to study their effect on the light-induced DNA cleavage.

\section{Materials and Methods}

\section{Reagents, Chemicals and Instruments}

Pyrene, 1-AP, and 1-HP were purchased from Aldrich Chemical Company (Milwaukee, WI) and used without further purification. Stock solutions (1 mM) were prepared in methanol and stored in brown containers in the refrigerator to exclude light. It was diluted with other solvents necessary to make the working solution before use. ФX 174 phage DNA (supercoiled RF-1 or sc-DNA) with a molecular weight of $3.6 \times 10^{6} \mathrm{Da}$ and 5386 base pairs was purchased from Promega Corporation (Madison, WI) and stored at $20^{\circ} \mathrm{C}$. Ethidium bromide (EB), bromophenol blue, xylencyanol, sodium chloride $(\mathrm{NaCl})$, potassium iodide (KI), magnesium chloride $\left(\mathrm{MgCl}_{2}\right)$, manganese chloride $\left(\mathrm{MnCl}_{2}\right)$, zinc chloride $\left(\mathrm{ZnCl}_{2}\right)$, cupric chloride $\left(\mathrm{CuCl}_{2}\right)$, ferric chloride $\left(\mathrm{FeCl}_{3}\right)$, riboflavin, histidine, mannitol, NAD, glutathione, and glutamic acid were purchased from Sigma-Aldrich (St Louis, MO). Agarose, calcium chloride $\left(\mathrm{CaCl}_{2}\right)$, sodium phosphate, TRIS-base, boric acid, and EDTA were purchased from Fisher Scientific
(Houston, TX). All solvents used were spectroscopic grade. The water used (18 $\mathrm{M} \Omega$ ) was deionized by a Barnstead Nanopure Infinity water de-ionization system (Dubuque, Iowa). A rapid agarose gel electrophoresis apparatus (C.B.S \& Scientific Co.) was used for gel electrophoresis. The NucleoVison Gel-Documentation System (NucleoTech Inc., CA) was used for quantification of the DNA.

\section{UVA-Light Induced DNA Cleavage}

Solutions (a total of $60 \mu \mathrm{l}$ of $10 \mathrm{mM}$ sodium phosphate at $\mathrm{pH} 7.1$ with $10 \%$ methanol) containing $\Phi X$ 174 phage DNA ( $27 \mu \mathrm{M}$ in base pairs), $0.6 \mu \mathrm{M} 1-\mathrm{HP}$ (or $6 \mu \mathrm{M} 1$-AP or $60 \mu \mathrm{M}$ pyrene), and a given biological ion or molecule were filled into the wells of a $3 \times 8$ flat bottomed Titertek ${ }^{\mathrm{TM}}$ plate (ICN Biochemical). These PAH concentrations were chosen to cause about $30 \%$ of DNA photocleavage under these experimental conditions. The plate was tightly covered with glass and placed onto a Pyrex glass support/filter, which was placed on an O-ring secured on a ring stand. The Pyrex glass served as a light filter to efficiently cut off any light below $300 \mathrm{~nm}$ that could damage DNA. A $100 \mathrm{~W}$ UVA lamp (type B, UVP Inc., Upland, CA) was placed beneath the Pyrex glass and the light was applied through the bottom of the Titertek plate from a fixed distance of $6.0 \mathrm{~cm}$. The UVA intensity of the light output was measure to be $170 \mathrm{~J} / \mathrm{cm}^{2}$ per hour of irradiation (UVA detector, Model PMA 2100, Solar Light Co., Inc., Philadelphia, PA). A stream of cold air was blowing toward the bottom of the Pyrex glass during the irradiation period to eliminate any heat. After irradiation, $12 \mu \mathrm{l}$ of a gel-loading dye solution (bromophenol blue and xylencyanol in 50\% glycerol) was added into each well of the Titertek plate and mixed. Then $14 \mu \mathrm{l}$ of the sample was loaded into the wells of the pre-prepared $1 \%$ agarose gel and subjected to electrophoresis at $100 \mathrm{~V}$ for 1-2h. Following electrophoresis, the gel was stained with Ethidium bromide $(2 \mathrm{mg} / \mathrm{L})$ and analyzed with the GelDocumentation System software. In the gel, there were two clear bands with the supercoiled DNA (sc-DNA) being the band further away from the origin and the relaxed open-circular DNA (oc-DNA) being the closer to the origin. The amount of sc-DNA and oc-DNA were quantified by the total fluorescence intensity of the bands after subtracting a common background as described in a previous publication [16].

\section{Results and Discussion}

Effect of Biologically Relevant Inorganic Ions on the Photocleavage of DNA

DNA photocleavage by 1-AP, 1-HP, or pyrene was carried out in the presence of biologically relevant inorganic ions. The choice of chloride salts is to eliminate any effect from the anion, because $\mathrm{Cl}^{-}$seems to have minimal effects on the light-induced DNA cleavage. All experiments were carried out with $27 \mu \mathrm{M}$ DNA and the results are shown in Figure 1 for pyrene 

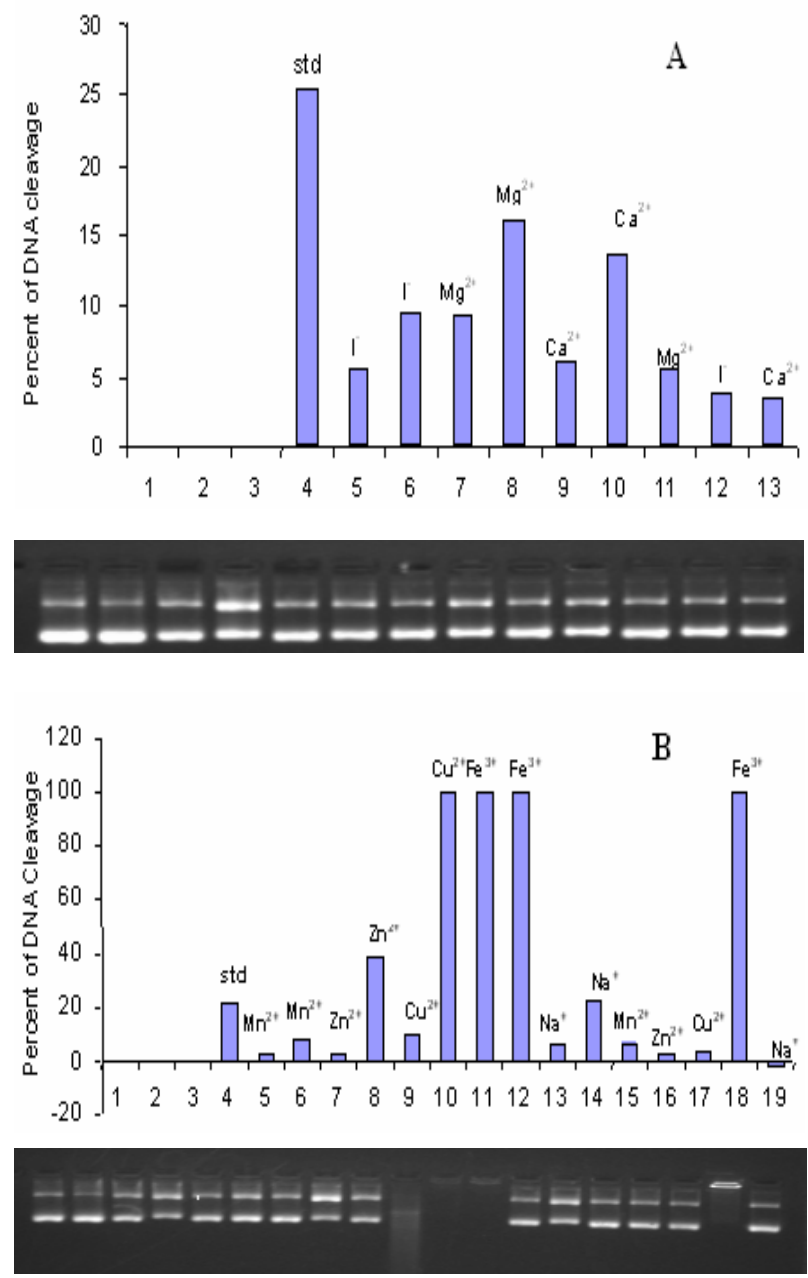

Figure 1: Effect of biologically relevant inorganic ions on the light-induced DNA cleavage by pyrene $(60 \mu \mathrm{M})$. Lanes 1, 2, 3 are negative controls and lane 4 is the positive control. The lower bands in the gel are that of the sc-DNA and the upper bands are that of the oc-DNA. The concentrations for various ions are: $50 \mathrm{mM}$ for $\mathrm{I}^{-}$, $\mathrm{Na}^{+}, \mathrm{Ca}^{2+}, \mathrm{Mg}^{2+}$ and $0.5 \mathrm{mM}$ for the transition metals $\mathrm{Mn}^{2+}, \mathrm{Zn}^{2+}, \mathrm{Fe}^{3+}$, and $\mathrm{Cu}^{2+}$. Experiments with all ions are under three conditions: (1) Dark control: Ion + DNA + pyrene without irradiation (Lanes 5, 7, 9 in A and 5, 7, 9, 11,13 in B); (2) Effect of ion on DNA cleavage by pyrene: ion + DNA + pyrene with $1 \mathrm{~h}$ of irradiation (Lanes 6, 8, 10 in A or 6, 8, 10, 12, 14 in B); (3) Light control: ion + DNA $+\mathrm{H}_{2} \mathrm{O}$ with $1 \mathrm{~h}$ of irradiation: (Lanes 11, 12, 13 in A or 15, 16, 17, 18, 19 in B).

and Table 1 for all three compounds. Lanes 1, 2, 3 in Figure 1 are the negative controls: DNA alone without light irradiation (lane 1), DNA alone with light irradiation (lane 2), and DNA $+60 \mu \mathrm{M}$ pyrene without irradiation (lane 3). They all have the same percent of oc-DNA indicating that exposure to light alone (lane 2) and pyrene alone (lane 3 ) does not cause any cleavage to the DNA. Lane 4 is the positive control with DNA and $60 \mu \mathrm{M}$ pyrene with $1 \mathrm{~h}$ of irradiation. It shows that about $26 \%$ of the sc-DNA is cleaved. The tests for each ion are with dark control (ion + pyrene + DNA without irradiation) and light control (ion + DNA with irradiation) in addition to the regular test (ion + pyrene + DNA with irradiation). The dark control experiments confirm that all ions except $\mathrm{Fe}^{3+}$ cause only minimal
DNA cleavage without light (lanes 5, 7, 9 in Figure 1A and 5, 7, 9, 13 in Figure $1 \mathrm{~B}) . \mathrm{Fe}^{3+}$ itself can cause the scDNA to become oc-DNA at a concentration of $0.5 \mathrm{mM}$ (lane 11 in Figure 1B). Light control with ions (without pyrene) shows the same trend as that for the dark control for most ions (except $\mathrm{Fe}^{3+}$ ) that they do not cause any cleavage to sc-DNA with $1 \mathrm{~h}$ of irradiation (lanes 11, 12, 13 in Figure $1 \mathrm{~A}$ and 15, 16, 17, 19 in Figure 1B). Among all ions tested, $\mathrm{Ca}^{2+}, \mathrm{Mg}^{2+}, \mathrm{Na}^{+}$, and $\mathrm{Mn}^{2+}$ have either minimal effects or cause a decrease of DNA photocleavage (Figure 1A and $\mathrm{B}$ ), whereas $\mathrm{Zn}^{2+}$ and $\mathrm{Cu}^{2+}$ enhance the DNA photocleavage by pyrene. The effect by $\mathrm{Fe}^{3+}$ cannot be assessed because $\mathrm{Fe}^{3+}$ itself can cause DNA cleavage.

Table 1: Effect of biologically relevant ions on the percent of DNA photocleavage by 1-hydroxypyrene (1HP), 1-aminopyrene (1-AP), and pyrene.

\begin{tabular}{lcccccccc}
\hline & $\Gamma$ & $\mathrm{Na}^{+}$ & $\mathrm{Mg}^{2+}$ & $\mathrm{Ca}^{2+}$ & $\mathrm{Mn}^{2+}$ & $\mathrm{Zn}^{2+}$ & $\mathrm{Cu}^{2+}$ & $\mathrm{Fe}^{3+}$ \\
\hline 1-HP & 23 & 20 & 10 & 9 & 12 & $22^{*}$ & $100^{*}$ & $100^{*}$ \\
Control & 40 & 40 & 40 & 40 & 18 & 18 & 18 & 18 \\
Pyrene & 10 & 23 & 16 & 14 & 8 & $39^{*}$ & $100^{*}$ & $100^{*}$ \\
Control & 26 & 22 & 26 & 26 & 22 & 22 & 22 & 22 \\
1-AP & $49 *$ & 34 & 35 & 25 & 15 & $65^{*}$ & $43^{*}$ & $100^{*}$ \\
Control & 38 & 38 & 38 & 38 & 38 & 38 & 38 & 38 \\
\hline
\end{tabular}

The error for each sample is about $\pm 20 \%$. $\mathrm{Fe}^{3+}$ can cause DNA cleavage without 1-HP, or pyrene, or light. The concentrations for various ions are: $50 \mathrm{mM}$ for I- $\mathrm{Ca}^{2+}, \mathrm{Mg}^{2+}, \mathrm{Na}^{+}$and $0.5 \mathrm{mM}$ for transition metals $\mathrm{Mn}^{2+}, \mathrm{Zn}^{2+}, \mathrm{Fe}^{3+}$, and $\mathrm{Cu}^{2+}$. The concentration for 1-AP, 1-HP, and pyrene are: $6,0.6$, and 60 $\mu \mathrm{M}$, respectively.

* Numbers represent enhancement on the DNA photocleavage.

Table 1 lists the percent of DNA photocleavage by pyrene, 1-AP, and 1-HP in the presence of various ions. The effect of most of the ions tested on 1-HP and 1-AP induced DNA photocleavage has the same trend as that for pyrene. Main group ions $\mathrm{Ca}^{2+}, \mathrm{Mg}^{2+}$ and $\mathrm{Na}^{+}$have either minimal effect or cause a small decrease. This indicates that the effect by these ions on the DNA photocleavage is negligible. Whereas transition mental ions, except for $\mathrm{Mn}^{2+}$ which inhibits DNA photocleavage, $\mathrm{Zn}^{2+}$ and $\mathrm{Cu}^{2+}$ can cause an enhancement for the DNA photocleavage by all three compounds. In the presence of $\mathrm{Cu}^{2+}$ sc-DNA is completely cleaved due to the exposure to pyrene or 1-HP and light (Table 1 and bar 10 in Figure 1B). It is only slightly enhanced, however, by the exposure to 1-AP and light (Table 1). Zinc ion enhances and manganese ion inhibits the DNA photocleavage by all three compounds. The mechanism of effect of each transition metal on DNA photocleavage still is not clear. But it has been reported that semicarbazide induces DNA damage in the presence of $\mathrm{Cu}^{2+}$ through the formation of hydrogen peroxide and semicarbazide-derived free radicals [20]. Thus, it is assumed that $\mathrm{Cu}^{2+}$ enhances the DNA photocleavage through $\mathrm{Cu}^{2+}$ or $\mathrm{PAH}$-derived free radicals. Although effect by $\mathrm{Fe}^{3+}$ cannot be assessed, in the presence of UV radiation, $\mathrm{Fe}^{3+}$ species also can undergo a photoredox 
process giving rise to $\mathrm{Fe}^{2+}$ and $\mathrm{OH}^{\bullet}$ hydroxyl radical [21] according to:

$$
\mathrm{Fe}^{3+}+\mathrm{H}_{2} \mathrm{O}+h v \rightarrow \mathrm{Fe}^{2+}+\mathrm{OH}^{\bullet}+\mathrm{H}^{+}
$$

$\mathrm{OH}^{\bullet}$ hydroxyl radical attacks and cleaves the DNA phosphate deoxyribose backbone in a largely sequenceindependent manner [22].

However, the effect by $\mathrm{I}^{-}$is different for 1-AP from 1-HP and pyrene, where $\mathrm{I}^{-}$enhances the DNA photocleavage by 1-AP and inhibits the DNA photocleavage by 1-HP and pyrene. This inhibitory effect on 1-HP or pyrene induced DNA photocleavage is in agreement with that $\mathrm{I}^{-}$inhibits the DNA photocleavage by 5 - and 7-methylbenz[a]anthracenes [15]. It is known that iodide ion is an excited singlet state quencher by enhancing the intersystem crossing rate from an excited singlet state to an excited triplet state [23]. Therefore, the fact that the presence of $\mathrm{I}^{-}$quenches the DNA photocleavage by either 1-HP or pyrene indicates that the singlet excited state of 1-HP or pyrene is involved in the DNA photocleavage process. Since the presence of KI enhances the DNA photocleavage by 1-AP, it must involve a different mechanism such as the involvement of the triplet state of 1-AP.

\section{Effect of Biologically Relevant Molecules on the Photocleavage of DNA}

DNA photocleavage induced by the combination of 1-AP, 1-HP, or pyrene and light were carried out in the presence of some biologically important molecules. The rationale is that PAHs in the cell are likely to co-exist with these molecules and these molecules may affect the ability of PAHs to cause DNA photocleavage. Except riboflavin, which by itself can cause DNA photocleavage, all the other chemicals, histidine $(5 \mathrm{mM})$, mannitol $(0.5 \mathrm{mM})$, NAD $(5 \mathrm{mM})$, glutathione $(0.5 \mathrm{mM})$, and glutamic acid $(0.5 \mathrm{mM})$ do not cause DNA cleavage upon light irradiation under these experimental conditions. The effect of these chemicals on DNA photocleavage is different for 1-AP, 1-HP or pyrene (Figure 2, Table 2). With 1-AP, all chemicals except glutathione, which inhibits the DNA photocleavage completely, enhance DNA photocleavage. For 1-HP, riboflavin, histidine and mannitol enhance DNA photocleavage, while glutathione and glutamic acid inhibit and NAD has no effect on DNA photocleavage. For pyrene, riboflavin, histidine and glutamic acid enhance DNA photocleavage, while NAD, glutathione, and mannitol have no effect on DNA photocleavage.
The varying effects seen here should be due to differences in chemical/photochemical reactions these three compounds initiate that lead to DNA photocleavage.

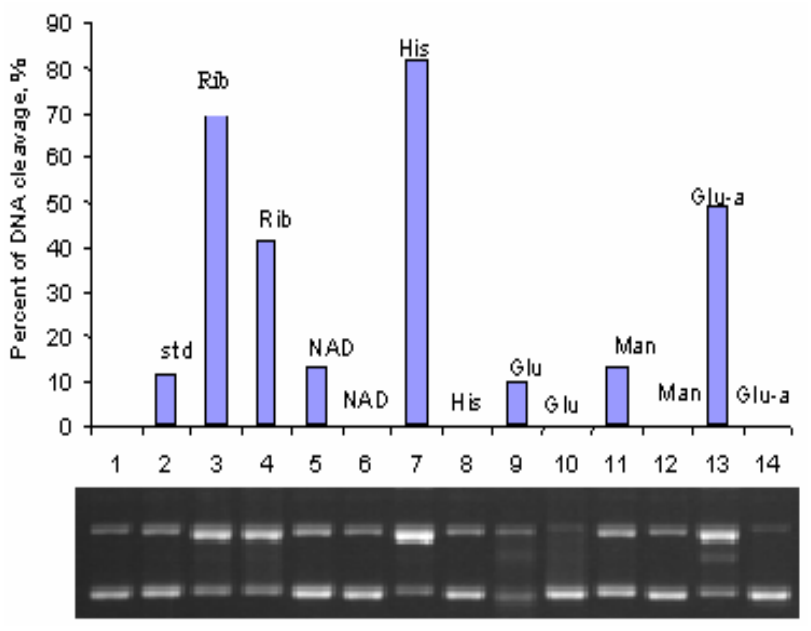

Figure 2: Effect of biologically relevant molecules on light-induced DNA cleavage by pyrene. $\Phi \mathrm{X}-174$ plasmid DNA $(27 \mu \mathrm{M}$ in base pairs) was mixed with $60 \mu \mathrm{M}$ pyrene and various biological chemicals and was irradiated for $1 \mathrm{~h}$ with a $100 \mathrm{~W}$ UVA lamp. Lane 1 is the dark control and lane 2 is the positive control with pyrene and DNA but without any added chemicals. Lanes 3, 5, 7, 9, 11, and 13 are the mixtures of DNA and pyrene irradiated for $1 \mathrm{~h}$ in the presence of riboflavin (5 $\mathrm{mM})$, NAD $(5 \mathrm{mM})$, Histidine $(5 \mathrm{mM})$, Glutathione $(0.5 \mathrm{mM})$, Mannitol $(0.5 \mathrm{mM})$, and Glutamic acid $(0.5 \mathrm{mM})$, respectively. Lanes $4,6,8,10,12,14$ are the same as $3,5,7,9,11$, and 13 , respectively, but without pyrene.

Riboflavin is a known photo-sensitizer that can facilitate light-induced chemical reactions of other compounds. The photodynamic action of riboflavin is generally considered to involve the generation of reactive oxygen species [24]. Photo-excited riboflavin gives rise to oxidative DNA damage predominantly by a type-I photoreaction, i.e. by direct one-electron or hydrogen transfer [25]. ESR experiments suggested that photo-excited riboflavin reacts with dGMP to produce riboflavin anion radical and guanine cation radical, but not with other mononucleotides. The estimated ratio of 8-OH-dG yield to total guanine loss indicates that the photo-excited riboflavin induces $8-\mathrm{OH}-\mathrm{dG}$ formation

Table 2: Percent of DNA photocleavage by 1-AP, 1-HP, and pyrene in the presence of biologically relevant molecules

\begin{tabular}{cccccccc}
\hline Control & $\begin{array}{c}\text { Riboflavin } \\
5 \mathrm{mM}\end{array}$ & $\begin{array}{c}\text { NAD } \\
5 \mathrm{mM}\end{array}$ & $\begin{array}{c}\text { Histidine } \\
5 \mathrm{mM}\end{array}$ & $\begin{array}{c}\text { Glutathione } \\
0.5 \mathrm{mM}\end{array}$ & $\begin{array}{c}\text { Mannitol } \\
0.5 \mathrm{mM}\end{array}$ & $\begin{array}{c}\text { Glutamic Acid } \\
0.5 \mathrm{mM}\end{array}$ \\
\hline $1-\mathrm{AP}$ & $15 \%$ & $76 \%^{*}$ & $59 \%^{*}$ & $55 \%^{*}$ & $0 \%$ & $34 \%^{*}$ & $34 \%^{*}$ \\
$1-\mathrm{HP}$ & $19 \%$ & $42 \%^{*}$ & $12 \%$ & $32 \%^{*}$ & $0 \%$ & $35 \% *$ & $7 \%$ \\
Pyrene & $11 \%$ & $65 \% *$ & $13 \%$ & $82 \% *$ & $10 \%$ & $13 \%$ & $49 \% *$ \\
\hline
\end{tabular}

The numbers are the percent of DNA cleavage caused by 1-AP, 1-HP, or pyrene upon light irradiation in the presence of one of the chemicals. The standard error is $\pm 20 \%$. * Numbers represent an enhancement. 
specifically at guanine residues located 5 ' to another guanine [26]. As a result, riboflavin can cause DNA photocleavage by itself on one hand, and it can enhance the ability of all the three compounds to cause DNA photocleavage, on the other.

Glutathione is a known reducing agent that usually traps free radicals such as hydroxyl free radicals [27]. Therefore, glutathione's role here seems to be as a free radical scavenger. It has been reported that both histidine and mannitol are singlet oxygen quenchers by reacting with singlet oxygen to produce oxidation products of histidine. Both should inhibit the DNA photocleavage. However, the presence of $5 \mathrm{mM}$ histidine and $0.5 \mathrm{mM}$ mannitol enhances the DNA photocleavage for all three compounds. This indicates that histidine and mannitol play roles other than quenching singlet oxygen. It has been confirmed that the presence of histidine greatly lengthens the degradation half-lives of various PAHs and inhibits their degradation [14]. Thus, the presence of histidine maintains a higher concentration of the PAHs that are capable of generating species other than singlet oxygen, such as superoxide or PAH free radicals, to cause DNA single-strand cleavage. The effect by mannitol is still not clear and needs further investigation.

\section{Concluding Remarks}

PAHs are ubiquitous environmental carcinogens and may co-exist with the biologically relevant ions and molecules in the cell. Since it is known that PAHs can cause light-induced DNA cleavage [15-17], they are photomutagenic toward Salmonella typhimurium bacteria strain TA102 [28], and genotoxic to human skin cells (unpublished results), the effect of co-existing chemicals on the light-induced DNA cleavage of PAHs is of interest to human health. It has shown in this paper that the effect by the co-existing molecules on the lightinduced DNA cleavage is complex. It depends on several factors:

1) Reactive species generated by photosensitization of a certain PAH compound leading to DNA photocleavage. These species include, but not limited to, singlet oxygen, superoxide, hydroxyl radical, PAH or DNA free radicals, and PAH or DNA adducts [10]. DNA cleavage can be caused by one or by a combination of several of these intermediates.

2) Nature of the co-existing chemicals. These chemicals can act either as scavengers of any of the aforementioned reactive species or as promoters of any of the intermediates that generates the reactive species. Because of these modifying effects, the phototoxicity of PAHs in cells should be studied in consideration of the co-existing chemicals.

Acknowledgments: This research was in part supported by the National Institutes of Health: NIH SCORE S06 GM08047 and the US Army Research Office DAAD 1901-1-0733 to JSU. We thank NIH-RCMI for core molecular and cellular biology and analytical facilities established at JSU.

\section{References}

1. Baum, E.: In Polycyclic Aromatic Hydrocarbons and Cancer; Gelboin, H., Ts'O, T., Eds.; Academic Press: New York, 1978, Vol. 1, p 45-70.

2. Connell, D. W.; Hawker, D. W.; Warne, M. J.; Vowles, P. P.: In Introduction into Environmental Chemistry; McCombs, K., Starkweather, A. W., Eds.; CRC Press LLC: Boca Raton, FL, 1997, p 205-217.

3. Pitot, H. C.: In Chemical Carcinogenesis and Mutagenesis I. Handbook of Experimental Pharmacology; Cooper, C. S., Growler, P. L., Eds.; Springer-Verlag: London, 1990, Vol. 94/I, p 2-29.

4. Kennaway, E. L.; Hieger, I.: Carcinogenic substance and fluorescence spectra, Brit. Med. J., 1930, 1, 1044-1046.

5. Cook, J. W.; Hewett, C. L.; Hieger, I.: The isolation of a cancer producing hydrocarbon from coal tar, $J$. Chem. Soc., 1933, 395-405.

6. Angerer, J.; Mannschreck, C.; Gundel, J.: Biological monitoring and biochemical effect monitoring of exposure to polycyclic aromatic hydrocarbons, Int. Arch. Occup. Environ. Health, 1997, 70, 365-377.

7. Harvey, R. G.: Polycyclic Aromatic Hydrocarbons: Chemistry and Carcinogenicity; Cambridge University Press: London, 1991.

8. Hemminski, K.; Grzybowska, E.; Chorazy, M.; Twardowska-Saucha, K.; Sroczynski, J. W.; Putman, K. L.; Randrath, K.; Phillips, D. H.; Hewer, A.; Santella, R. M.; Perera, F. P.: In Complex Mixtures and Cancer Risk; Vainio, H., Sorsa, M., McMichael, A. J., Eds.; IARC Scientific Publisher: Lyon, France, 1990, Vol. 104, p 181-192.

9. Arfsten, D. P.; Schaeffer, D. J.; Mulveny, D. C., The effects of near ultraviolet radiation on the toxic effects of polycyclic aromatic hydrocarbons in animals and plants: A review, Ecotoxicol. Environ. Safety, 1996, 33, 1-24.

10. Yu, H., Environmental carcinogenic polycyclic aromatic hydrocarbons: photochemistry and phototoxicity, $J$. Environ. Sci. \& Health, Part C-Environ. Carcinog. \& Ecotoxic. Revs, 2002, C20, 149-183.

11. Conney, A. H.: Induction of microsomal enzymes by foreign chemicals and carcinogenesis by polycyclic aromatic hydrocarbons, Cancer Res., 1982, 42, 4875-4917.

12. Devanesan, P. D.; Higginbotham, S.; Ariese, F.; Jankoviak, R.; Suh, M.; Small, G. J.; Cavalier, E. L.; Rogan, E. G.: Depurinating and stable benzo[a]pyrene-DNA adducts formed in isolated rat liver nuclei, Chem. Res. Toxicol., 1996, 9, 1113-1116.

13. Dipple, A.: Polycyclic aromatic hydrocarbons and carcinogenesis; Ameraican Chemical Society: Washington, DC, 1985.

14. Dong, S.; Fu, P. P.; Hwang, H.-M.; Yu, H.: Effects of histidine on light-induced DNA single strand cleavage by selected polycyclic aromatic hydrocarbons, Polycycl. Arom. Compd., 2002, 22, 451-458.

15. Dong, S.; Fu, P. P.; Shirsat, R. N.; Hwang, H.-M.; Leszczynski, J.; Yu, H.: UVA light-induced DNA cleavage by isomeric methylbenz[a]anthracenes, Chem. Res. Toxicol., 2002, 15, 400-409. 
16. Dong, S.; Hwang, H.-M.; Harrison, C.; Holloway, L.; Shi, X.; Yu, H., UVA light-induced DNA cleavage by selected polycyclic aromatic hydrocarbons, Bull. Environ. Contam. Toxicol., 2000, 64, 467-474.

17. Dong, S.; Hwang, H.-M.; Shi, X.; Holloway, L.; Yu, H., UVA-induced DNA single strand cleavage by 1hydroxypyrene and formation of covalent adducts between DNA and 1-hydroxypyrene, Chem. Res. Toxicol., 2000, 13, 585-593.

18. Swartz, R. C.; Ferraro, S. P.; Lamberson, J. O.; Cole, F. A.; Ozretich, R. J.; Boese, B. L.; Schults, D. W.; Behrenfeld, M.; Ankley, G. T., Photoactivation and toxicity of mixtures of polycyclic aromatic hydrocarbon compounds in marine sediment, Environ. Toxicol. Chem., 1997, 16, 2151-2157.

19. Pelletier, M. C.; Burgess, R. M.; Ho, K. T.; Kuhn, A.; McKinney, R. A.; Ryba, S. A.: Phototoxicity of individual polycyclic aromatic hydrocarbons and petroleum to marine invertebrae lavae and juveniles, Environ. Toxicol. Chem. 1997, 16, 2190-2199.

20. Chen, F.; Oikawa, S.; Hiraku, Y.; Murata, M.; Yamashita, N.; Kawanishi, S., Metal-mediated oxidative DNA damage induced by nitro-2aminophenols, Cancer Lett., 1998, 126, 67-74.

21. Miguel; Rodriguez, A. K.; Contreras, Sandra; Charnarro, Esther, Esplugas, Santiago: Influence of $\mathrm{H}_{2} \mathrm{O}_{2}$ and $\mathrm{Fe}$ (III) in the photodegradation of nitrobenzene, Photochem. Photobiol., 2000, 133, 123-127.
22. Strahs. D., S. T.: Accessibility of deoxyribose protons and cleavage by hydroxyl radical, Department of Chemistry and Courant Institute of Mathematical Sciences New York University and Howard Hughes Medical Instute, 2000.

23. Miller, J. C.; Meek, J. S.; Strickler, S. J.: Heavy Atom Effect on the TRiplet Lifetime of Naphthalene and Phenathrene, J. Am. Chem. Soc., 1977, 99, 8175-8179.

24. Iyad, A.; Mansour, K. M.; Gatasheh.; Imrana, N., Hemolysis of human red blood cells by riboflavin$\mathrm{Cu}$ (II) system, BBA, 2000, 1523 (2-3), 225-229.

25. Schulz, I.; Mahler, H.; Bioteux, S.; Epe, B.: Oxidative DNA base damage induced $b$ singlet oxygen and photosensitization: recognition by repair endonucleases and mutagenicity, Mutation Res., 2000, 461, 145-156.

26. Ito, K.; Inoue, S.; Yamamoto, K.; Kawanishi, S.: 8Hydroxydeoxyguanosine formation at the 5' site of 5'GG-3' sequences in double-stranded DNA by UV radiation with riboflavin, Biological Chemistry, 1993, 268, 13221-13227.

27. Ohta, Y.; Shiraishi, N.; Nishikawa, T.; Nishikimi, M.: Copper-catalyzed autoxidations of GSH and L-ascorbic acid: mutual inhibition of the respective oxidations by their coexistence, BBA, 2000, 1474 (3), 378-382.

28. Yan, J.; Wang, L.; Fu, P. P.; Yu, H.: Photomutagenicity of sixteen polycyclic aromatic hydrocarbons in the US EPA priority pollutant list, Mutat. Res., 2004, 557, 99-108. 